\title{
The Unconstitutionality of Transferable Development Rights
}

Transferable development rights (TDR) systems have been widely acclaimed by many planners, government officials and lawyers as a panacea which will enable municipalities to finance the preservation of landmarks and open spaces. ${ }^{1}$ It is envisioned as a method which will impose neither a hardship on the owners of preserved parcels nor an expense on the municipality. ${ }^{2}$

The classic application of TDR arises in the context of landmark preservation in central city locations. ${ }^{3}$ Most landmarks do not utilize the maximum floor area ratio permitted under existing zoning law. ${ }^{4}$ For the owner, this results in an economically inefficient use of scarce urban land. ${ }^{5}$ By replacing landmarks with new buildings which utilize the maximum floor area ratio, owners of landmarks could realize increased returns due to intensified use. Great pressures are thus placed on the owner to raze the landmark and rebuild.

TDR is a device by which a landowner may be compensated for the restriction placed on his right to realize these increased returns from his parcels. Under TDR, a permanent prohibition is issued

1. See, e.g., J. Costonis, Space Adrift xvi (1974) (quoting Ada Louise Huxtable); Costonis, Development Rights Transfer: An Exploratory Essay, 83 YALE L.J. 75 (1973); Elliott \& Marcus, From Euclid to Ramapo: New Directions in Land Development Controls, 1 Hofstra L. Rev. 56, 72 (1973); Gilbert, Saving Landmarks: The Transfer of Development Rights, Historic Preservation, July-Sept. 1970, at 13; Morris, Zoning ImaginationDimensional Zoning, 46 ST. JoHN's L. REv. 679, 686 (1972).

The rising importance of TDR in the land planning field is evidenced by the fact that at a recent conference of the American Society of Planning Officials, TDR was the focus of the entire symposium. The speakers consisted of planners, lawyers and government officials, and included both advocates and opponents of TDR. Bettman Symposium, Am. Soc'y of Planning Officials, May 12, 1974. The proceedings of the Bettman Symposium will be published as Am. Soc'y of Planning Officials, Transferable Development Rights (Planning Advisory Serv. Rep. No. 304, 1975).

2. J. Cosronis, supra note 1 , at 36 .

3. Application of TDR is not limited to the preservation of landmarks; it may also be used to preserve existing open spaces by transferring development rights to other areas from the land sought to be preserved. See, e.g., Costonis, sutpra note 1, at 91-95 (discussing the preservation of Phosphorescent Bay, Puerto Rico). This Note, however, will focus on the traditional context of TDR: preservation of central city landmarks.

4. The floor area ratio is a figure set by the city as part of its zoning plan which expresses the total allowable floor area of a building as a multiple of the area of the lot. Multiplying this figure by the area of the lot determines the maximum floor area that may be built. The floor area ratio thus controls the density of construction on the lot.

5. Landmarks may also be cconomically inefficient to the owner because of some dysfunctional structural aspects, e.g., an old building may be inordinately expensive to heat. If such a building is utilizing its maximum floor area ratio, TDR will not be available as a means of preservation. 
against using the "excess development potential" of the land. In the system presently operating in New York City, ${ }^{6}$ the landowner is then compensated for this limitation by the issuance of freely transferable development rights in an amount equivalent to the amount of development potential the landowner is prohibited from using. The landowner may either retain these rights for his own use or sell them to other landowners or developers. The holder of these development rights, whether the original recipient or a subsequent purchaser, may then build a structure, in a designated transfer district, which has a floor area ratio in excess of that normally permitted under the zoning plan in that district. Alternatively, instead of issuing development rights to the owner, the city may condemn the excess development potential, compensate the landowner in cash, and sell the development rights itself to recoup the costs of compensation. This type of system, currently in effect in Chicago, is referred to as the "development rights bank."7

Although TDR is a relatively new concept, many areas of the country are in the process of adopting variations on the basic forms of TDR systems. ${ }^{8}$ These proposals are not unopposed, however. Many social and political criticisms have been levelled against TDR: it will lead to chaos in planning;' it will interfere with existing bonus systems; ${ }^{10}$ it is unnecessary where there are other tools available for preservation purposes; ${ }^{11}$ and it will increase the density in already congested areas. ${ }^{12}$ The rapidity with which TDR systems are being adopted suggests that these potential problems may not be receiving sufficient consideration.

This Note will identify the constitutional objections to TDR that have already arisen and are likely to arise in the future. It will then

6. See New York, N.Y., Zoning Resolution art. 7, ch. 4, \$\$ 74-79, 791-93 (1971).

7. This is the type of system advocated by John $J$. Costonis of the University of Illinois. For a discussion comparing the development rights bank and the New York system, see Costonis, The Chicago Plan: Incentive Zoning and the Preservation of Urban Landmarks, 85 HARv. L. REv. 574 (1972).

8. TDR enabling legislation or ordinances are presently being considered in New Jersey, Vermont, Puerto Rico, and two counties in California (Marin and Mono). Addresses by Robert DeVoy, Ellis Gans, David Heater, and Sydney Willis, Bettman Symposium, Am. Soc'y of Planning Officials, May 13, 1974. For TDR systems which have been enacted, see Ill. REv. STAT. ch. 24, \$\$ 11-48.2-1 (1971); NEW YoRK, N.Y. ZoNiNG Resolution art. 7, ch. 4, $\$$ 74-79, $791-93$ (1971).

9. Beverly Moss Spatt, Dissent from Resolution CP-21166 of the N.Y.C. Planning Comm'n to the Board of Estimate, May 13, 1970, cited in J. CosToNis, supra note 1, at 130; Marcus, Air Rights Transfers in New York City, 36 Law \& Contemp. Prod. 372, 387 (1971).

10. See Note, Development Rights Transfer in New York City, 82 YALE L.J. 338, 371

n.162 (1972). For a discussion of bonus systems, see note 57 infra.

11. Id. at 370 .

12. Id. at 371 . 
explore the possible ways in which TDR may be redesigned to avoid such objections, and present a legal framework for evaluating the constitutionality of these redesigned TDR systems. The ultimate conclusion is that TDR will not survive the tide of constitutional challenges it is likely to face. This suggests that the use of TDR may result in the loss of many great landmarks. ${ }^{13}$ Municipalities should therefore turn to other means of landmark preservation, rather than take the substantial risk that TDR will prove to be inadequate. ${ }^{14}$

\section{The Landmark Owner Sues the City: The Taking Issue}

The few cases $^{15}$ that have been litigated in the area of TDR suggest that landmark owners will assert both that the restrictions imposed on the use of their land amount to an exercise of the power of eminent domain for which compensation is required, ${ }^{16}$ and that transferable development rights are not adequate compensation. Before a determination is made as to the adequacy of compensation, the issue of whether the TDR system constitutes an application of the power of eminent domain, requiring compensation, must be settled.

13. A good example of this possibility is the recent loss of Grand Central Station. See pp. 1108-09 infra. Great public concern was expressed over the loss of this landmark. See Goldberger, Cily's Naming of Grand Central As $A$ Landmark Voided By Court, N.Y. Times, Jan. 22, 1975, at 49, col. 2; Goldin, Policy on Landmarks Must Be Reassessed, N.Y. Times, Mar. 23, 1975, $\$ 8$, at 1, col. 1; Henry, Jackie Onassis Fights For Cause, N.Y. Times, Jan. 31, 1975, at 35, col. 5; Huxtable, Why Did We Lose Grand Central As A Landmark?, N.Y. Times, Feb. 2, 1975, \$2, at 26, col. 1 .

14. Rather than utilizing unreliable methods of shifting preservation costs onto a select group (whether developers or ardent supporters of landmark preservation), as is done by TDR systems, the municipality itself should assume responsibility for saving landmarks. This could be done, for example, by offering tax relief to landmark owners (see note 24 infra) or by appropriating public funds either to acquire historic easements or to provide compensation for outright condemnation. See, e.g., Wilson \& Winkler, The Response of State Legislation to Historic Preservation, 36 LAW \& Contemp. Prob. 329 (1971). For Kentucky's approach, see Schroder, The Preservation of Historical Areas, 62 Ky. L.J. 940 (1974).

In addition to being an unreliable approach, TDR may also impair the effectiveness of possible alternative methods for accomplishing landmark preservation. First, challenges upon the validity of TDR increase the administrative costs of preservation, including legal fees and court costs, thereby depleting a potential source of funds for compensating landmark owners. Second, landmark owners may seek damages for revenue losses resulting from the unlawful preservation restriction on their property, further reducing the funds available for compensation. Finally, the uncertainties and expense involved in an unreliable system of preservation might cause municipal officials to be reluctant to designate landmarks, for fear that they will be forced to surrender under constitutional attack. Therefore, a more conventional method of preservation which makes use of tax relief and cash compensation for outright condemnation is advocated.

15. Penn Central Transp. Co. v. City of New York (Sup. Ct. N.Y. Co. Jan. 21, 1975), in N.Y.L.J., Jan. 23, 1975, at 16, col. 3; Fred F. French Investing Co., Inc. v. City of New York, 77 Misc. 2d 199, 352 N.Y.S.2d 762 (Sup. Ct. 1973).

16. The Fifth Amendment of the United States Constitution states that private property shall not be "taken for public use, without just compensation.". The Fourteenth Amendment has been interpreted to impose the same obligation on states and municipalities. McCoy v. Union Elevated R.R., 247 U.S. 354 (1918); Appleby v. City of Buffalo, 221 .U.S. 524 (1911); Chicago, B. \& Q. R.R. v. Chicago, 166 U.S. 226 (1897). 


\section{A. Eminent Domain versus Police Power}

The distinction between an exercise of the power of eminent domain and an exercise of the police power has plagued legal commentators and judges for nearly a century. ${ }^{17}$ In attempts to make sense of the existing maze of judicial opinions, or to advocate sounder principles to guide future judicial thought, many tests for distinguishing between the two have been devised. Some of the most widely accepted of these tests include the physical invasion test, ${ }^{18}$ the degree or extent of harm test, ${ }^{19}$ the harm/benefit test ${ }^{20}$ and the arbitralenterprise capacity test. ${ }^{21}$ Each of these tests has been criticized for

17. See, e.g., Goldblatt v. Town of Hempstead, 369 U.S. 590 (1962); Pennsylvania Coal Co. v. Mahon, 260 U.S. 393 (1922) (Holmes, J., viewed the distinction as requiring that a line be drawn somewhere along a continuum); Mugler v. Kansas, 123 U.S. 623 (1887) (Harlan, J., for the court, seeks a qualitative difference between the police power and the power of eminent domain); Lutheran Church in America v. City of New York, 35 N.Y.2d 121, 316 N.E.2d 305, 359 N.Y.S.2d 7 (1974); F. Bosselman, D. Callies \& J. Banta, The Taking Issue (1973) [hereinafter cited as Bosselman]; Abbott, The Police Power and the Right to Compensation, 3 Harv. L. Rev. 189 (1889); Michelman, Property, Utility, and Fairness: Comments on the Ethical Foundations of "Just Compensation" Lau', 80 HaRv. L. REv. 1165 (1967); Sax, Takings and the Police Power, 74 YALE L.J. 36 (1964).

18. The physical invasion test requires that an actual physical appropriation or divesting of title occur. Therefore, regulation which constitutes indirect and consequential injuries to property would not constitute a taking. BosselMAN, supra note 17, at 106, 115-20. This test has been criticized for exalting form over substance. Sax, supra note 17, at 46-48. It has been suggested that physical invasion is a sufficient but not a necessary condition for a taking to have occurred. Michelman, supra note 17, at 1184 .

19. The degree or extent of harm test distinguishes between eminent domain and the police power on the basis of the degree of diminution in the value of the property. "Essentially the theory appears to express two interrelated ideas: (1) that all legally acquired existing economic values are property, and (2) that while such values may be diminished somewhat without compensation, they may not be excessively diminished...." Sax, supra note 17, at 50 (footnotes omitted). However, little correlation has been found between the extent of loss in land value and the judicial distinction between the police power and eminent domain. $1 \mathrm{R}$. ANDERson, AMERICAN Law of Zoning $\$ 2.23$, at 101 (1968). See Goldblatt v. Town of Hempstead, 369 U.S. 590, 594 (1962); Hadacheck v. Sebastian, 239 U.S. 394 (1915) (diminution of value from $\$ 800,000$ to $\$ 60,000$ upheld); Turnpike Realty Co. v. Town of Dedham, 284 N.E.2d 891, 900 (Mass.), cert. denied, 409 U.S. 1108 (1972); Sax, supra note 17, at 51 .

20. The harm/benefit test distinguishes between the two powers on the basis of whether the governmental purpose is to prevent a harm or to confer a benefit. If the purpose of the regulation is to prevent a harm it is an exercise of the police power. If the regulation attempts to confer a benefit on the public at the expense of a private landowner, it constitutes an exercise of the power of eminent domain. This test is primarily criticized on the ground that it is difficult, if not impossible, to distinguish rationally and consistently between preventing a harm and compelling a landowncr to confer a benefit. Michelman, supra note 17 , at 1201. But see Dunham, $A$ Legal and Economic Basis for City Planning, 58 Colum. L. REv. 650, 664 (1958).

21. The arbitral-enterprise capacity distinction is made on the basis of the capacity in which the government is acting when it imposes the restriction. If the government is acting as an arbitrator in settling conflicts between two private parties it is exercising its police power. However, if the government takes private resources to provide for the public good it is acting in its enterprise capacity and compensation is required. Lutheran Church in America v. City of New York, 35 N.Y.2d 121, 128-29, 316 N.E.2d 305, 310, 359 N.Y.S.2d 7, 14 (1974); Sax, supra note 17, at 62-63.

Michelman has criticized the analytical foundation of this test by asking:

If there is something "wrong" with deliberate collective action which diminishes a

few people's welfare in the course of augmenting the welfare of "the public" at large, 
being theoretically unsound, failing to produce consistency in the case law and providing both over- and under-inclusive definitions of compensable takings. ${ }^{22}$ The courts themselves have hesitated to employ any one test to distinguish a compensable taking from a noncompensable exercise of the police power. Instead, they have articulated a case-by-case approach to the problem. ${ }^{23}$ Therefore, a survey of recent case law rather than an analysis under one of these tests may provide a better indication of whether the use of TDR to preserve landmarks (or open space) will be held by the courts to be an exercise of the police power or of the power of eminent domain.

There is strong case law support for the proposition that a private owner must be permitted to realize a reasonable return on his property, ${ }^{24}$ but a taking does not occur simply because the property could be used in a more valuable way were it not for the zoning classification. ${ }^{25}$ While the concept of a reasonable return is elusive, courts have

why is that something not so virulently present when those who stand to benefit at the expense of these same few people are "private" property owners rather than a "public" one?

Michelman, supra note 17 , at 1201. Michelman also suggests that the judicial tendency has been to deal more leniently with restrictions designed to promote public rather than private ends. Id. at 1201 n.76.

22. See, e.g., Bossel.MAN, supra note 17; Michelman, supra note 17, at 1183-1201; Sax, supra note 17, at 46.50; Van Alstyne, Taking or Damaging by Police Power: The Search for Inverse Condemnation Criteria, 44 S. CAL. L. REv. 1, 14 (1971). An extensive discussion of the merits of each test is beyond the scope of this Note. The concern here is whether the courts will be more likely to hold TDR to be an exercise of the police power or an exercise of the power of eminent domain, rather than the most appropriate theory for the courts to use in reaching their conclusion.

23. Goldblatt v. Town of Hempstead, 369 U.S. 590, 594 (1962); United States v. Central Eureka Mining Co., 357 U.S. 155, 168 (1958); United States v. Caltex, Inc., 344 U.S. 149, 156 (1952); National Bd. of YMCA v. United States, 396 F.2d 467, 473 (Ct. Cl. 1968), aff'd, 395 U.S. 85 (1969); Consolidated Rock Prods. Co. v. City of Los Angeles, 57 Cal. $2 d$ 515, 20 Cal. Rptr. 638, 370 P.2d 342, appeal dismissed, 371 U.S. 36 (1962); Aronson v. Town of Sharon, 346 Mass. 598, 603, 195 N.E.2d 341, 344-45 (1964).

24. Metropolitan Bd. of Zoning Appeals v. Gateway Corp., 268 N.E.2d 736, 740 (Ind. 1971); Harrington Glen, Inc. v. Municipal Bd. of Adjustment, 52 N.J. 22, 33, 243 A.2d 233, 239 (1968); Morris County Land Improvement Co. v. Township of Parsippany-Troy Hills, 40 N.J. 539, 557, 193 A.2d 232, 241-42 (1963); Lutheran Church in America v. City of New York, 35 N.Y.2d 121, 130, 316 N.E.2d 305, 311, 359 N.Y.S.2d 7, 15 (1974); In re Trustees of the Sailors' Snug Harbor v. Platt, 29 App. Div. 2d 376, 378, 288 N.Y.S.2d 314, 316 (1968); Penn Central Transp. Co. v. City of New York (Sup. Ct. N.Y. Co., Jan. 21, 1975), in N.Y.L.J., Jan. 23, 1975, at 16, col. 3; Greenhills Home Owners Corp. v. Village of Greenhills, 202 N.E.2d 192, 197-98 (Ohio Ct. App. 1964), rev'd on other grounds, 5 Ohio St. 2d 207, 215 N.E.2d 403 (1966); Multnomah County v. Howell, 9 Ore. App. 374, 384, 496 P.2d 235, 239 (1972); Saravo Bros. Constr. Co. v. Zoning Bd. of Review, Town of Johnston, 231 A.2d 9 (R.I. 1967). Use of this approach is not limited to the area of zoning. See, e.g., In re Central R.R. Co., 485 F.2d 208 (3d Cir. 1973), cert. denied, 414 U.S. I131 (1974); Sax, Takings, Private Property and Public Rights, 81 YAle L.J. 149, 156-57 (1971); Note, Takings and the Public Interest in Railroad Reorganization, 82 YALE L.J. 1004 (1973).

25. M\&N Enterprises, Inc. v. City of Springfield, 111 Ill. App. 2d 444, 449, 250 N.E.2d 289, 292 (1969); Rebman v. City of Springfield, Ill Ill. App. 2d 430, 438-39, 250 N.E.2d 282, 286-87 (1969); Morris County Land Improvement Co. v. Township of Parsippany-Troy Hills, 40 N.J.2d 539, 557, 193 A.2d 232, 242 (1963); Multnomah County v. Howell, 9 Ore. App. 374, 380, 496 P.2d 235, 238 (1972). 
given content to this concept by comparing the return on the property subject to the alleged taking with the return allowed by the municipality's land use regulations on similarly situated properties that are not landmarks. ${ }^{26}$

Typical of this approach is Lutheran Church in America v. City of New York, ${ }^{27}$ the most recent decision by a state supreme court regarding the constitutionality of landmark preservation restrictions. In Lutheran Church the Landmarks Preservation Commission of New York City designated as a landmark a building owned by the Church and ordered that it be preserved. This prevented any modification of the exterior of the building. The New York Court of Appeals held that, under the facts of the case, the Church was entitled to compensation. The court appeared to have initially applied the harm/benefit test $^{28}$ and the enterprise-arbitral capacity distinction ${ }^{28}$ to determine whether the designation was a taking that required compensation. When the Commission's order failed to satisfy either of those tests, the court considered whether the restrictions imposed by the Commission permitted the landowner to realize a reasonable return on the property and held that they did not:

[W] hile such designation might not wreak confiscatory results in all situations (as where business might well be promoted by the designation) it does have that effect here where plaintiff is $d e$ prived of the reasonable use of its land. ${ }^{30}$

26. Rebman v. City of Springfield, 111 Ill. App. 2d 430, 437, 250 N.E.2d 282, 286 (1969); Metropolitan Bd. of Zoning Appeals v. Gateway Corp., 268 N.E.2d 736, 742 (Ind. 1971); Lutheran Church in America v. City of New York, 35 N.Y.2d 121, 124, 316 N.E.2d 305, 307, 359 N.Y.S.2d 7, 10 (1974); Penn Central Transp. Co. v. City of New York (Sup. Ct. N.Y. Co., Jan. 21, 1975), in NY.L.J., Jan. 23, 1975 at 16, col. 4.

Preservation restrictions may be distinguished from general zoning provisions, which are generally held valid as an exercise of the police power:

$[T]$ he preservation ordinance compels the landmark owner at his own expense to confer a benefit on the community: it freezes his property in its current state while leaving unrestrained the range of development options open to his neighbors. The 'harm' that it prevents, moreover, is simply the discontinuance of a community benefit fortuitously provided by the owner. In contrast, the zoning ordinance prevents the property owner from increasing the profitability of his land by engaging in an activity that would visit demonstrable physical and economic harm on his neighbors. Because it leaves the owner with precisely the same range of development options as those his neighbors enjoy, he is no worse off under it than they.

$\mathrm{J}$. Costonis, supra note 1 , at 18.

27. 35 N.Y.2d 121, 316 N.E.2d 305,359 N.Y.S.2d 7 (1974).

28. [O]f course, where property is being put to a noxious use such use can be enjoined under the common law doctrine of nuisance, and ... no compensation would be due, the injunction having been for the common good and there having been no specific taking.

Id. at 128,316 N.E. $2 \mathrm{~d}$ at 310,359 N.Y.S.2d at 14 .

29. Id. at 128-29, 316 N.E.2d at 310,359 N.Y.S.2d at 14 (citing Sax, supra note 17, at 62-63).

30. Id. at 130, 316 N.E.2d at 311,359 N.Y.S.2d at 15 (emphasis added). 
In looking at the return the Church received on its property, the court gave some consideration to the return accruing on other properties similarly situated. ${ }^{31}$

If the preservation restrictions imposed under a TDR system allow a reasonable return to the landmark owner, TDR will not involve a taking. It is unlikely, however, that TDR will be used to preserve a landmark that is producing a reasonable return for in such situations more efficient means for preserving landmarks may be available. ${ }^{32}$ In practice TDR would be confined to those situations where no reasonable return can be realized if the landmark is to be preserved. ${ }^{33}$ Therefore, where TDR is employed, restrictions on the landmark owner's right to use his property normally will involve a taking for which compensation is required, rather than a noncompensable regulation under the police power.

\section{B. Development Rights as Just Compensation}

Once TDR is found to be a taking, the question then becomes whether the freely transferable development rights awarded to the landmark owner by the city constitute just compensation. ${ }^{34}$ The two cases to date that raise this issue have held that such rights do not adequately compensate for the taking..$^{35}$

In Fred F. French Investing Company, Inc. v. City of New York (Tudor City), a mortgagee brought an action against the city challenging a zoning amendment which established a special park district out of part of the land securing his mortgage. The amendment also

31. The court noted in particular that the structure in question was not a part of a preservation district and that it was surrounded by modern multistory structures. Id. at 124,316 N.E.2d at 307,359 N.Y.S.2d at 10.

32. One method is for the city to grant tax relief to the landmark owner. See, e.g., 2 New York, N.Y., Charter AND ADMinistrative Code art. 7, ch. 8-a, $\$ 207-5.0$, a, (1)-(2) (1971). In New York City this is supposed to be the first step taken when a landmark owner demonstrates that he cannot realize a reasonable return on his property (a reasonable return being defined as a net annual return of 6 percent of assessed valuation). The TDR system for landmarks preservation was enacted to supplement rather then replace the tax relief provisions. Ncw York City llanning Commission, Minutes 302 (May 1, 1968), cited in Note, supra note 10 , at 351 n.77.

33. See, e.g., Penn Central Transp. Co. v. City of New York (Sup. Ct. N.Y. Co., Jan. 21,1975 ), in N.Y.L.J., Jan. 23, 1975, at 16, col. 3, discussed at pp. 1108-09 infra. Fred F. French Investing Co. Inc. v. City of New York, 77 Misc. 2d 199, 352 N.Y.S.2d 762 (Sup. Ct. 1973), discussed at pp. 1107-08 infra.

34. Where just compensation has been paid, restrictions on a landowner's reasonable use of his property have been unheld. See, e.g., United States v. Albrecht, 496 F.2d 906 (8th Cir. 1974) (U.S. condemncd an easement requiring landowner to maintain pot holes on property for waterfowl preservation purposes.)

35. Penn Central Transp. Co. v. City of New York (Sup. Ct. N.Y. Co., Jan. 21, 1975), in N.Y.L.J., Jan. 23, 1975, at 16, col. 3; Fred F. French Investing Co., Inc. v. City of New York, 77 Misc. 2d 199, 352 N.Y.S.2d 762 (Sup. Ct. 1973).

36. 77 Misc. 2d 199, 352 N.Y.S.2d 762 (Sup. Ct. 1973). 
required the owner of the property involved to maintain a private park as a recreational area for the public. The city, apparently in an attempt to provide compensation, authorized the issuance of transferable development rights. ${ }^{37}$ The court viewed TDR as raising a broad constitutional issue regarding the distinction between the police power and the power of eminent domain,,$^{38}$ and found the city's actions to be a taking. ${ }^{39}$ It then held that compensation in the form of development rights was constitutionally inadequate:

Pursuant to this action, the owner is confronted with the problem of acquiring 30,000 square feet of property suitable for his purpose in the newly prescribed area but he is left to his own resources for acquisition and funding in what may be an unpredictable market of the future. ${ }^{40}$

The court ordered that the area be returned to its original zoning.41

The second action which challenged a TDR system involved the preservation of Grand Central Terminal in New York City.2 Since Grand Central Terminal had been declared a landmark, its facade could not be altered without permission from the Landmarks Preservation Commission. In April, 1969, the Landmarks Preservation Commission refused to permit the demolition of the Grand Central Terminal in order to allow a 59-story office building to be erected in its place. ${ }^{43}$ Donald H. Elliot, the Planning Commission Chairman, offered to amend the Zoning Resolution to allow Penn Central to

37. In what appears to be recognition by the city for the need of some modicum of compensation, provision was made for the owners to be granted a waiver of zoning regulations in another area conveniently removed from the environs of the United Nations and the residents of Tudor City, and the transfer of air rights which could be utilized in contravention of any existing zoning, in the area bounded by 38 th Street to 60th Street and from Third to Eighth Avenues.

Id. at 201,352 N.Y.S.2d at 764 .

38. Id. at 202,352 N.Y.S.2d at 765 .

39. The decision was based on the fact that the zoning amendment destroyed the economic value of the land. Id. at 202,352 N.Y.S.2d at 766.

40. Id. at 201,352 N.Y.S.2d at 765 .

41. The court also held that the theory of inverse condemnation was inapposite because no actual taking had yet occurred. Inverse condemnation occurs when a landowner asserts a claim that his property has been appropriated by the state, and is then awarded compensation for the taking. Selby Realty Co. v. City of San Buenaventura, 10 Cal. 3d 110, 119-20, 514 P.2d 111, 117, 109 Cal. Rptr. 799, 805 (1973); Ferguson v. Village of Hamburg, 272 N.Y. 234, 240, 5 N.E.2d 801, 803 (1936).

42. Penn Central Transp. Co. v. City of New York (Sup. Ct. N.Y. Co., Jan. 21, 1975), in N.Y.L.J., Jan. 23, 1975, at 16, col. 3. The case was not decided until over five years after suit was filed. The court severed the Railroad's damage claim for loss of income caused by the prohibition against construction of the tower during the delay, and this issue is still undecided.

43. The Commission had also rejected an alternate proposal, made by Penn Central in September of the preceding year, to maintain the facade of the Terminal but to build a modern office tower on top of it. Shipler, New Tower Sought For Grand Central, N.Y. Times, Apr. 11, 1969, at 1, col. 7 . 
transfer the excess development potential to parcels it owned throughout Manhattan, rather than requiring the development rights to be transferred only to adjacent parcels. ${ }^{4-4}$ However, since most of the property which the railroad owned was already encumbered with longterm leases, the increased development potential was virtually worthless. Penn Central filed suit against New York City, alleging that the Commission's actions went beyond the scope of permissible regulation and constituted an unconstitutional taking of the railroad's property without just compensation. ${ }^{45}$ The court, after first finding that there had been a taking because the railroad was prevented from realizing a reasonable return on its property, ${ }^{46}$ held that the transferable development rights were not adequate compensation:

There is no provision of the Landmarks Law which affords relief to the plaintiffs, with respect to the Terminal or the Terminal site, against the economic hardship which they suffered as a result of the defendants' actions under the Landmarks Law. ${ }^{47}$

The court based this conclusion on its finding that, under the facts of the case, there were no suitable parcels to which the development rights could be transferred. ${ }^{48}$

44. Id. at 28 , col. 1 .

45. Penn Central Sues City In Fight To Build Grand Central Tower, N.Y. Times, Oct. 8, 1969, at 51, col. 2.

46. This holding was supported by findings of fact that the terminal was deteriorating at a substantial rate and needed expensive repairs and maintenance work; that the site was a valuable location for an office building and that the Terminal had originally been designed with the intent of constructing a 20-story office tower on top of it; and that the cost to Penn Central of operating the Terminal had greatly exceeded the revenues received from tenants and concessionaires. Penn Central Transp. Co. v. City of New York (Sup. Ct. N.Y. Co., Jan. 21, 1975), in N.Y.L.J., Jan. 23, 1975, at 16, col. 6-7.

The court also held that there had been a denial of equal protection. $I d$. at col. 8 . While the court was not explicit, the basis of this holding is suggested by the inclusion in the opinion of the following quotation from former Judge Van Voorhis' report as special master in the debtor reorganization of the Penn Central Railroad:

It is doubtful that the City could insist upon the [Terminal] being maintained at

Penn Central's expense as a memorial to the golden age of railroading. The building,

as it is, is expensive to maintain, and even under the broad scope of the police

power in modern times it is doubtful that it can be so constricted [sic] withont there

being a taking without payment of just compensation as required by the state and

federal constitutions. This is particularly true in view of the similarity and close proximity to the Pan Am Building which, it might be argued, could constitute discrimination denying the equal protection of the law.

Id. at col. 4.

47. Id. at col. 8.

48. The court found that:

The property principally suggested for the transfer of development rights is the present site of the Biltmore Hotel. Development rights could not be economically transferred to the Biltmore site because:

(1) The Biltmore Hotel is and has been a profitable operation.

(2) A building on the Biltmore site could not have been profitable because (a) the ground rent required of UGP [the lessee of the property] by Penn Central for a lease of the Biltmore site was $\$ 2,000,000$ a year more than in the Terminal lease, and 
Neither of these two cases held the Landmark Preservation Law unconstitutional on its face. Rather, both cases held the statute unconstitutional as applied because the transferable development rights were not adequate compensation in the particular circumstances of each case. It does not appear, however, that the impact of Tudor City and Grand Central on TDR will be narrowly circumscribed, since the underlying difficulty in each case is likely to exist in virtually any use of TDR: the value of transferable development rights will always be determined by and fluctuate with the market for these rights.

The adequacy of compensation was challenged in both Grand Central and Tudor City because compensation in the form of development rights is not a sum certain payment. ${ }^{49}$ This stems from the fact that the market for development rights, if it exists, determines their value. $^{50}$ Since the market is determinative, there is no guarantee that

(b) there would have been increased costs of construction, financing taxes and building operation.

(3) Rents from an office building on the Biltmore site would be significantly lower than from one on the Terminal site which is a superior location.

Id. at col. 8.

49. This is the major problem Costonis foresees for TDR. Address by John Costonis, Bettman Symposium, Am. Soc'y of Planning Officials, May 13, 1974.

The Supreme Court has repeatedly stated that compensation must be the full monetary equivalent of the property taken. See, e.g., Almota Farmers Elevator \& Whse. Co. v. United States, 409 U.S. 470, 473-74 (1973); United States v. Reynolds, 397 U.S. 14, 16 (1970); United States v. Miller, 317 U.S. 369, 373 (1943); Monongahela Navigation Co. v. United States, 148 U.S. 312, 326 (1893); Porter v. United States, 473 F.2d 1329, 1334 (5th Cir. 1973). However, since the Court has never been confronted with a case involving nonmonetary compensation, it has not actually held that compensation is necessarily inadequate if it is nonmonetary in form, and this remains an open question. Blanchette v. Connecticut Gen. Ins. Corps., 95 S. Ct. 335, 361-63 (1974). Therefore, it is possible that development rights may be inadequate as compensation not only because they do not constitute a sum certain payment and hence may not be equivalent in value to the property taken, but also because they are a nonmonetary form of payment.

50. David Richards, an outspoken opponent of TDR, suggests that one example of the uncertainty of the market is the possibility of future zoning amendments. For instance, if the zoning of the transfer district was subsequently amended to increase the allowable floor area ratio, the value of the development rights already issued would decline because the market demand for the rights would be decreased. Similarly, downzoning the transfer district (see note 56 infra) would lead to an increase in the value of previously issued development rights. Address by David Richards, Bettman Symposium, Am. Soc'y of Planning Officials, May 13, 1974.

It may be argued that even where the form of compensation renders its actual value uncertain, an expected value may be determined by attaching probabilities to all possible future events that would effect the valuation of the compensation. See, e.g., Grayson, The Use of Statistical Techniques in Capital Budgeting, in FINANCIAL RESEARCH AND Management Decisions 98-107 (D. Robichek ed. 1967). For a discussion of the application of this theory in another area of the law, see, e.g., Consolidated Rock Prods. Co. v. DuBois, 312 U.S. 510 (1941); Note, Giving Substance to the Bonus Rule in Corparate Reorganization: The Investment Value Doctrine Analogy, 84 YALE L.J. 932 (1975). In the case of development rights, however, the requirement of a sum certain payment is justifiable. There is always the opportunity for an abuse of discretion by city governments, since cities have the power, through future zoning amendments and variances, ultimately to control the value of the very rights they have issued. Requiring sum certain compensation eliminates the potential for abuse. 
the landowner will receive compensation equivalent to his loss. ${ }^{51}$ The landowner is assured only whatever value the market places on freefloating development rights, sold unattached to a parcel upon which to use such rights. In the context of a heavily developed central city, the market for development rights may be weak or nonexistent because all the parcels to which the rights could be transferred might already be intensively built up. ${ }^{52}$ It is unlikely that, in an area already heavily developed, an increase in the floor area ratio can be achieved which will increase the return on the parcel sufficiently to outweigh the cost to a developer of razing an existing structure, purchasing development rights, foregoing income for a relatively long period during construction, constructing a new building and paying higher taxes.53

An additional problem arises if the landowner chooses to use the development rights himself. The landowner cannot use these rights unless he either buys a parcel specifically for that purpose or happens to own a suitable parcel in the transfer district. If he does not already own such a site, an additional investment of some kind will be necessary for the landowner to take advantage of this form of compensation. There is no guarantee, however, that a suitable parcel will be available or that the landowner will have the resources to purchase the parcel. ${ }^{54}$

\section{Difficulties in Establishing a Market for Development Rights}

Development rights, due to their speculative nature, are not likely to be viewed by courts as just compensation. Therefore, methods must

51. The value of the compensation received by a landmark owner will be the mathematical product of the quantity of rights he receives multiplied by the value of each right. TDR is designed to redistribute development potential rather than increase the overall density of the city, and hence it does not expand the total amount of development in the city. See J. Cosronis, supra note 1, at 33-34. Therefore, the landmark owner is entitled to receive only the quantity of development rights that is equal in terms of floor area ratio to the condemned development potential of his lot. Since the quantity of rights the landmark owner will receive is thus fixed, the variable factor on which the value of the compensation depends is the value the market attaches to each unit of development rights. Therefore, the only method available to ensure just compensation to landmark owners under a TDR system is to ensure adequate market demand for development rights. See pp. 1112-13 infra.

52. Ironically, a similar problem would also arise in the situation of underdeveloped urban areas, where there would be insufficient development to create effective market demand for development rights. David Heater discussed this problem in the context of a proposal for the preservation of open space in Vermont. Address by David Heater, Bettman Symposium, Am. Soc'y of Planning Officials, May 13, 1974.

53. While the cost of adding floors to existing structures might be less expensive, it would probably be rare that an existing structure would be adaptable for such purposes.

54. This problem was raised by the court in Tudor City. Fred F. French Investing Co., Inc. v. City of New York, 77 Misc. 2d 199, 201, 352 N.Y.S.2d 762, 765 (Sup. Ct. 1973), discussed at p. 1108 supra. 
be devised to remedy this defect.55 There are at least two ways in which a city may avoid the problem of the speculative nature of development rights. The first is to continue to issue development rights, as in the New York City system, but to prevent the problem of uncertain valuation from ever arising. Landmark owners are unlikely to challenge the program in court if the market value of the transferable development rights adequately reflects the value of what has been taken. This will occur only if there exists a market demand for development rights. To ensure such a demand, the transfer district will have to be carefully chosen and development in the district strictly controlled. Furthermore, down-zoning, ${ }^{56}$ the elimination of bonus systems, ${ }^{57}$ and stricter standards for granting variances may become necessary.

55. Because of the difficulties of raising preservation funds and because TDR is a means of preserving landmarks without any cost to the municipality, it is likely that municipalities will feel a strong temptation to redesign rather than abandon TDR. This contention finds support in the Grand Central case. Prior to filing suit, the railroad complained that development rights which could only be transferred to adjacent parcels had absolutely no value, because the adjacent parcels were already intensively developed. Instead of paying compensation, Donald Elliott, then Chairman of the Planning Commission, responded with an offer to amend the Zoning Resolution in order to allow transfer to parcels owned by the railroad throughout Manhattan. Shipler, New Tower Sought For Grand Central, N.Y. Times, Apr. 11, 1969, at 1, col. 7. See pp. 1108.09 supra.

56. Down-zoning is the process by which a municipality imposes more restrictive zoning than that to which a parcel had been subject previously. The constitutional questions raised by down-zoning to create a market for development rights are beyond the scope of this Note. However, it is highly questionable that an exercise of the police power of zoning may be justified solely by fiscal considerations without regard to promoting the general welfare. See 122 Main St. Corp. v. City of Brockton, 323 Mass. 646, 650, 84 N.E.2d 13, 16 (1949); Oakwood At Madison, Inc. v. Township of Madison, 117 N.J. Super. 11, 18, 283 A.2d 353, 357 (1971); Horn Constr. Co. v. Town of Hempstead, 41 Misc. 2d 438, 443, 245 N.Y.S.2d 614, 619-20 (Sup. Ct. 1963); Scannell v. City of Dunkirk, 16 Misc. 2d 957, 960, 182 N.Y.S.2d 590, 593 (Sup. Ct.), rev'd on other grounds, 9 App. Div. 2d 725, 192 N.Y.S.2d 192 (1959); 1 R. ANDERSON, supra note 19, \$ 7.31, at 555.

Moreover, down-zoning only the transfer district may provoke transfer district developers to assert claims of invalid spot zoning. Traditional spot zoning occurs when a parcel of land within a use district is marked off into a separate district, thereby permitting a use that would be impermissible in the original district. Such zoning is invalid where the change is not in accordance with the comprehensive zoning plan, where there is an absence of mistake or changed circumstances, and where there is no reasonable relation to the public health, safety and welfare. See, e.g., Coughlin v. City of Topeka, 206 Kan. 552, 480 P.2d 91 (1971); Cassel v. Mayor \& City Council of Baltimore, 195 Md. 348, 73 A.2d 486 (1950); Pierce v. King County, 62 Wash. 2d 324, 382 P.2d 628 (1963); cf. Sears, Roebuck \& Co. v. City of Alexandria, 155 So.2d 776 (La. Ct. App.), cert. denied, 245 La. 83, 157 So. 2d 230 (1963). Down-zoning may be viewed as a kind of "negative" spot zoning. Rather than singling out an enclave within a particular district for a more beneficial use which may have adverse effects on the larger district, as in spot zoning, down-zoning forces a small enclave to bear the adverse effects of more restrictive zoning, arguably without a reasonable relation to public welfare. Therefore, down-zoning only the transfer district under a TDR system should be subject to the same restrictions that apply to traditional spot zoning.

57. A bonus system enables developers to increase the floor area ratio permitted on their lots by providing certain amenities. See Note, supra note 10 , at 371 n.162. Therefore, it competes with TDR as a means for building in excess of the limits set by the zoning law. Developers may favor the bonus system rather than the TDR system cven if the cost of providing the amenity is greater than the purchase price of the development 
The second method of avoiding the problem of an uncertain, nonmonetary payment, is to abandon the New York City program and institute instead a development rights bank. In such a system the landmark owner is compensated in cash for the taking, and the city bears the burden of recouping the cost of the landmark preservation program by selling the development rights directly to developers. The landmark owner, compensated in cash, will not be in a position to object to the speculative value of the development rights. However, if TDR is to serve its purpose of establishing a financially independent preservation program, the city will ultimately be faced with the same problem that it faced under the New York City TDR system. A market which adequately reflects the value of the condemned rights must exist in order for the city to recoup its costs of preservation by the sale of development rights. While the city may be able to retain the development rights for some period in the hope that a market will develop, it cannot do so forever. Eventually, the lack of a natural market for development rights will impose sufficient financial pressure on the city to necessitate the creation of a market demand for development rights. ${ }^{58}$

Although the just compensation issue may be circumvented in either of these two ways, both solutions shift the costs onto developers in the designated transfer district. This is an attempt to single out from all other business activities the enterprise of development; and even further, within this group, it is an attempt to single out only new development within the transfer district. Developers in a transfer district will experience higher construction costs relative both to new structures in other areas of the city and to existing structures in the transfer district, if they are required to purchase development rights in order to build comparable structures. Since the whole city benefits from the preservation of landmarks, imposing the cost on a select group may be met with claims of arbitrariness and unreasonableness. Therefore, if the city requires developers in a transfer district to purchase development rights in order to provide compensation for landmark owners, these developers may sue the city.

rights: the developer who elects the bonus system not only gets the increased floor area, but also gets an amenity which may attract more customers for his tenants or make the building more attractive to the tenants themselves. Therefore, part of his expenditure may be recouped in higher rentals or a greater percentage of occupancy. See generally Comment, Bonus or Incentive Zoning-Legal Implications, 21 SrRAcusE L. REv. 895 (1970).

58. Since TDR is used as a self-sufficient technique for financing the preservation of landmarks, it is reasonable to assume that the city will not be in a financial position both to wait indefinitely for a market to develop and to purchase additional development rights in order to preserve other landmarks which are threatened. 


\section{The Developer Sues the City: Police Power and Special Assessment}

The law of subdivision exactions provides developers with a legal framework for challenging the TDR system regardless of which method the city chooses to circumvent objections of the landmark owners. ${ }^{53}$ Although subdivision exactions grew out of early regulations designed to produce more accurate title records ${ }^{60}$ and to control the layout of development, ${ }^{61}$ they were later transformed into a method for financing municipal facilities and services. ${ }^{62}$ Recordation or approval of subdivision plats was conditioned on the provision by the developer of such facilities as streets, sewers and water mains. Alternatively, the developer could pay a fee in lieu of dedication which would be applied toward the cost of the needed services. ${ }^{63}$

There are several reasons why an analogy between subdivision exactions and TDR may be useful to developers. First, both TDR and subdivision exactions impose an expense upon the landowner as the condition for allowing development. ${ }^{64}$ Moreover, TDR and subdivision exactions attempt to internalize the costs of development to the process itself. The development process generates the pressure for the destruction of landmarks by creating a demand for higher density uses of those parcels which do not utilize the maximum floor area potential. ${ }^{65}$ Much as in the subdivision exaction context where the

59. While down-zoning, elimination of bonus systems, and stricter control over variances may lead to higher construction costs and thereby provoke objections from developers, by analogy to the subdivision exaction cases they are not necessary elements of the developers' cause of action against the municipality. Therefore, developers can object even if a market already exists, although in practice it is unlikely that they will do so.

60. C. Berger, LAND OWNERShip AND USE 846 (1968); Johnston, Constitutionality of Subdivision Control Exactions: The Quest For A Rationale, 52 CoRNELL L.0. 871, 874 (1967); Reps, Control of Land Subdivision by Municipal Planning Boards, 40 CoRNELL L.Q. 258 (1955).

61. See, e.g., Village of Lynbrook v. Cadoo, 252 N.Y. 308, 314-15, 169 N.E. 394, 396-97 (1929); Reps, supra note 60 .

62. See, e.g., Ayres v. City Council of the City of Los Angeles, 34 Cal. 2d 31, 20t P.2d 1 (1949); C. BERGER, supra note 60, at 847.

63. A fee in lieu of dedication is a cash payment made by a subdivider, at the option of the municipality, as an alternative to the dedication of land or the provision of facilities. See, e.g., City of Buena Park v. Boyar, 186 Cal. App. 2d 61, 8 Cal. Rptr. 674 (1960); Jordan v. Village of Menomonee Falls, 28 Wis. 2d 608, 137 N.W.2d 442 (1965), appeal dismissed, 385 U.S. 4 (1966); C. BERGER, supra note 60 , at 847 .

64. While subdivision exactions may also require the dedication of land or provision of public facilities, TDR will only involve the payment of cash (either to the landmark owner or to the city) to purchase development rights. However, the two situations are nonetheless analogous. Upon the assumption of an expense (either payment or fee, or dedication of land or provision of public facilities in the case of subdivision exactions), the developer in both cases is permitted to use his land in a way that produces higher returns than would otherwise be possible.

65. Costonis, supra note 1; Address by John J. Costonis, Bettman Symposium, Am. Soc'y of Planning Officials, May 13, 1974. 
cost of new facilities is placed on those who burden existing facilities, TDR imposes the cost of landmark preservation on the development process that provided the impetus for the destruction of the landmarks. Furthermore, while both TDR and subdivision exactions result in the imposition of costs directly upon the developer, such costs may be passed on to the ultimate consumer. ${ }^{B 6}$ Finally, both TDR and subdivision exactions are attempts to provide funds for expenditures traditionally financed out of general tax revenues. ${ }^{67}$ Therefore, the extensive body of case law that has developed in the area of subdivision exactions may, by analogy, be applied to the problem of transferable development rights.

Courts have applied two different standards in evaluating the constitutionality of subdivision exactions: the police power theory and the special assessment theory. ${ }^{68}$

\section{A. The Police Power Theoryos}

The police power approach to subdivision exactions is often justified by reliance upon the "privilege" rationale. ${ }^{70}$ The "privilege" in

66. For an extensive discussion of whether developers actually possess the market power to pass on these costs, see Note, Subdivision Land Dedication: Objectives and Objections, 27 Stan. L. Rev. 419, 428-29 n.24 (1975).

In the case of subdivisions the ultimate consumers are the purchasers of the subdivided lots. In the case of TDR, the ultimate consumers are the lessees or purchasers of office or apartment space in buildings that were constructed using transferable development rights. In the subdivision exaction field, the fact that a developer may hope to recoup his added cost from the consumer has not meant that he will not object to the burden of the assessment. Similarly, in the context of TDR a developer is likely to object even though the cost may be passed on, because he will be put in a disadvantageous position relative to the owners of existing structures and to developers of new structures which are not in a transfer district.

67. In systems other than TDR, the costs of preservation of landmarks and open spaces are generally assumed by the community through the exercise of the power of eminent domain or the provision of tax relief. Subdivision exactions may be used to fund school systems and recreational facilities which were traditionally financed through the general tax structure, and to provide sewers and streets which originally were provided by municipal agencies. See, e.g., Ayres v. City Council of the City of Los Angeles, 34 Cal. 2d 31, 207 P.2d I (1949); City of Buena Park v. Boyar, 186 Cal. App. 2d 61, 8 Cal. Rptr. 674 (1960); C. BERCER, supra note 60 , at 846-47.

68. Costonis, supra note 1, at 109-10; Heyman \& Gilhool, The Constitutionality of Imposing Increased Community Costs on New Suburban Residents Through Subdivision Exactions, 73 YALE L.J. 1119 (1964).

69. In litigation instituted by the developer, the police power issue is not settled by the likelihood that the courts will view TDR as an exercise of the power of eminent domain in suits by the landmark owner against the city. The developer will not focus on the taking of the development rights, but rather upon the issue of whether the city's efforts to create a market for the sale of development rights is a valid exercise of the police power.

70. Associated Home Builders of the Greater East Bay, Inc. v. City of Walnut Creek, 4 Cal. 3d 633, 644, 484 P.2d 606, 615, 94 Cal. Rptr. 630, 639, appeal dismissed, 404 U.S. 878 (1971); Jordan v. Village of Menomonee Falls, 28 Wis. 2d 608, 619-20, 137 N.W.2d 442, 447, appeal dismissed, 385 U.S. 4 (1966). But see Landau, Urban Concentration and Land Exactions for Recreational Use: Some Constitutional Problems in Mandatory Dedication Ordinances in Iowa, 22 Drake L. Rev. 71, 81-82 (1972). 
this case ${ }^{\pi 1}$ is that of being permitted by the city to record or to subdivide. In the case of TDR, the privilege is the grant of a zoning variance which allows the owner of the development rights to build in excess of the specified floor area ratio.

In addition to requiring that a privilege be conferred, the police power theory also requires the subdivision exaction or dedication to meet the "uniquely attributable" 72 test; that is, it must be shown that the need for new facilities was created by the subdivider and not by the total development of the community. ${ }^{73}$ However, in recognition of the difficulty of attributing the need to any particular subdivision, the courts have upheld an exaction where the municipality can establish that a group of separate subdivisions have been responsible for the influx of people, thus necessitating the increase in community facilities for which the exaction is levied. ${ }^{74}$

The police power approach to subdivision exaction cases may be applied to TDR. ${ }^{75}$ Arguably, the process of development exerts a

71. This is in contradistinction to the "benefit" used in special assessment theory. See pp. 1118-19 infra.

72. Aunt Hack Ridge Estates, Inc. v. Planning Comm'n, 160 Conn. 109, 273 A.2d 880 (1970); People ex rel. The Exchange National Bank v. City of Lake Forest, 40 Ill. 2d 281, 287, 239 N.E.2d 819, 822 (1968); Pioneer Trust \& Sav. Bank v. Village of Mount Prospect. 22 Ill. 2d 375, 381, 176 N.E.2d 799, 802 (1961); McKain v. Toledo City Plan Comm'n, 26 Ohio App. 2d 171, 176, 270 N.E.2d 370, 374 (1971); Frank Ansuini, Inc. v. City of Cranston, 264 A.2d 910, 913 (R.1. 1970). Under the uniquely attributable test, the cost of the facilities may be assessed against the particular subdivision only when the need for certain facilities was actually created by that subdivision. This should be carefully contrasted with the test applied under special assessment theory. The latter permits a municipality to exact fees for benefits accruing to the subdivision from facilities financed by the exaction. See pp. 1118-19 infra. The question of need, and thus the uniquely attributable test, is not relevant in applying the special assessment theory. See Associated Home Builders v. City of Walnut Creek, 4 Cal. 3d 633, 484 P.2d 606, 94 Cal. Rptr. 630 (1971). Because the court in Walnut Creek applied the special assessment theory, it dismissed the subdivider's arguments based on the uniquely attributable test, and focused instead on the special benefits which would have accrued primarily to the subdivision from park land purchased by a fee in lieu of dedication. Walnut Creek is confusing because it appears to uphold as an exercise of the "police power" an exaction from a subdivision, to pay for recreational facilities, even though the need for such facilities was not uniquely attributable to that particular subdivision. However, the term "police power" was used by the court in its generic sense as the power to regulate for the general public welfare, rather than referring to the police power theory applied in subdivision exaction cases. Since the subdivision in Walnut Creek would benefit from the park land financed by the exaction, the fee was properly sustained under the special assessment theory. See note 79 infra.

73. See, e.g., Pioneer Trust \& Sav. Bank v. Village of Mount Prospect, 22 Ill. 2d 375, 381-82, 176 N.E.2d 799, 802 (1961); Billings Properties, Inc. v. Yellowstone County, I44 Mont. 25, 35, 394 P.2d 182, 188 (1964).

74. See, e.g., Associated Homebuilders v. City of Walnut Creek, 4 Cal. 3d 633, 638, 484 P.2d 606, 610, 94 Cal. Rptr. 630, 634, appeal dismissed, 404 U.S. 878 (1971); Jordan v. Village of Menomonee Falls, 28 Wis. 2d 608, 617-18, 137 N.W.2d 442, 447-48, appeal dismissed, 385 U.S. 4 (1966). A unique feature of Jordan was the fact that an actual study had been made which "determined that land valued at $\$ 200$ would by and large provide the added park and school lands required for each family brought into the village by the creation of the subdivision." Id. at 614-15, 137 N.W.2d at 446.

75. This dual test, i.e., whether some benefit or privilege is granted by the municipality and whether the need for the service or facility is uniquely attributable to those upon 
pressure on landmarks which may lead to their destruction. However, although the pressure to replace landmarks with more intensive land uses may be attributable to the development process itself, TDR ignores the requirement that the need for the expenditure be uniquely attributable to the particular developer upon whom the cost is imposed. The entire financial burden of preservation cannot be justifiably placed solely upon those who purchase development rights, for it is unlikely that the creation of the need can be uniquely attributed to such developers. This situation is analogous to that in subdivision cases, where the growth of the entire community rather than the development of a particular subdivision has generated the need for the additional facilities. ${ }^{76}$ Moreover, TDR cannot be justified by those. subdivision cases that uphold an exaction imposed upon a group of developers collectively responsible for creating the need for the new facilities. While it may be possible to attribute the need for preserving a landmark to all developers throughout the city, TDR singles out only those developers in the transfer district to bear the cost. ${ }^{7}$ "Therefore, in a suit brought by a developer, TDR should not be upheld on the police power theory. ${ }^{78}$

whom the financial burden falls, has not been limited to the realm of subdivision exactions. It has also been applied in other contexts to determine the validity of an exercise of the police power which has fiscal consequences. See, e.g., Portland Pipe Line Corp. v. Environmental Improvement Comm'n, 307 A.2d 1, 21-22 (Me. 1973) (upholding a licensing fee for overwater transfer of petroleum products because the fee would be used to protect against oil spills, a danger caused by those who would pay the fee and receive the benefit from the insurance provisions of the fund generated from such fees); Garden State Racing Ass'n v. Cherry Hill Township, 42 N.J. 454, 458, 201 A.2d 554, 560 (1960) (upholding licensing fee for operation of parking lot because added costs of maintenance, repair and traffic supervision were generated by racetrack traffic).

76. Pioneer Trust \& Sav. Bank v. Village of Mount Prospect, 22 Ill.2d 375, 381-82, 176 N.E.2d 799, 802 (1961).

77. The technique of financing preservation through a tax imposed on all new development is still of questionable validity. Where licensing and inspecting fees for regulating construction greatly exceed the cost of such regulation and are used to obtain additional revenue for general expenditures, they will be invalidated as a tax:

The philosophy of [these] ordinance[s] is that the tax rate of the borough should remain the same and the new people coming into the municipality should bear the burden of the increased cost of their presence. This is so totally contrary to tax philosophy as to require it to be stricken down.

Daniels v. Borough of Point Pleasant, 23 N.J. 357, 362, 129 A.2d 265, 267 (1957). See, e.g., Merrelli v. City of St. Clair Shores, 355 Mich. 575, 96 N.W.2d 144 (1959); Colonial Oaks West, Inc. v. Township of East Brunswick, 61 N.J. 560, 296 A.2d 653 (1972); Weber Basin Home Builders Ass'n v. Roy City, 26 Utah 2d 215, 487 P.2d 866 (1971). But cf. Associated Home Builders of Greater East Bay, Inc. v. City of Newark, 18 Cal. App. 3d 107, 95 Cal. Rptr. 648 (1971) (upholding $a$ tax on the business of construction, even though the amount of the tax was measured by the number of bedrooms constructed and the revenue from the tax went into the general capital outlay fund).

78. The court's choice of whether to apply the police power or special assessment theory may well be determinative of the result in a subdivision exaction case. Based on the same facts each test may suggest a different outcome. See, e.g., Jordan v. Village of Menomonee Falls, 28 Wis. 2d 608, 619-20, 137 N.W.2d 442, 448-49 (1965), appeal dismissed, 385 U.S. 4 (1966) (the majority, applying the police power test, unheld a compulsory dedication because it met the privilege and uniquely attributable tests; the 


\section{B. Special Assessment Theory}

Under the special assessment theory the property assessed must receive some special benefit distinct from any benefit enjoyed by the general public. ${ }^{79}$ In the situation of subdivision exactions, the special

dissent applied the special assessment theory and reached a contrary result because there was no assurance that a special benefit would accrue to the subdivision).

The distinction between the special assessment and police power doctrines rests upon the distinction between the taxing power and police power. See, e.g., Santa Clara County Contractors and Homebuilders Ass'n v. City of Santa Clara, 232 Cal. App. 2d 564, 580, 43 Cal. Rptr. 86, 96 (1965); Kelber v. City of Upland, 155 Cal. App. 2d 631, 638, 318 P.2d 561,565 (1957); Haugen v. Gleason, 226 Ore. 99, 104, 359 P.2d 108, 111 (1969). This classification in general depends on the primary purpose of the governmental action: "If the purpose is regulation the imposition ordinarily is an exercise of the police power, while if the purpose is revenue the imposition is an exercise of taxing power and is a tax." 4 T. Cooley, Taxation \$ 1784, at 3509 (1924). See, e.g., Brackman v. Kruse, 122 Mont. 91, 104, 199 P.2d 971, 977 (1948); C.L. Maier Co, v. City of Canton, 94 Ohio L. Abs. 434, 436-37, 28 Ohio Op. 2d 229, 230, 201 N.E.2d 609, 611 (1964); Bossert v. City of Okmulgee, 97 Okla. Crim. 140, 143, 260 P.2d 429, 433 (1953); Haugen v. Gleason, 226 Ore. 99, 104, 359 P.2d 108, 110-111 (1961); Producers Ass'n v. City of San Antonio, 326 S.W.2d 222, 224 (Tex. 1959); House of Tobacco, Inc. v. Calvert, 394 S.W.2d 654, 656-57 (Tex. 1965); State of Alaska v. Baker, 64 Wash. 2d 207, 212-14, 390 P.2d 1009, 1012-14 (1964), appeal dismissed, 380 U.S. 260 (1965).

While the decision to designate landmarks is based upon aesthetic justifications, the financing of their preservation through TDR is justified solely through fiscal considerations. It is clear that TDR is not grounded in the police power, since the increase in floor area ratio obtained through the purchase of development rights neither prevents an evil nor promotes the general welfare. Rather, the sale of development rights is equivalent to the sale of a zoning change, because its sole justification is to raise revenue. See Note, supra note 10 , at $361 \mathrm{n} .124$. The revenue-raising implications of TDR are twofold. First, the sale of development rights, either by the landmark owner or the city, provides the funds for compensating the landmark owner. See J. Costonis, supra note 1, at 36. Second, the sale of development rights by the city will supply tax revenue which would not have been available under other methods of preservation. See New York City Planning Commission, Minutes 303 (May 1, 1968), cited in Note, supra note 10, at 352 n.81. Under traditional methods of preservation, tax revenue is lost because potentially taxable development is prohibited on the landmark site. TDR, on the other hand, transfers this potentially taxable development to a site where it can be taxed. J. Costonis, supra note 1 , at 41.42 . Therefore, because TDR is justified solely by its ability to raise revenue (albeit for landmark preservation), it will resemble an exercise of the taxing power and be subject to the special assessment test rather than the police power test. But see Costonis, supra note 1, at 111:12.

79. See Nev-Cal Elec. Sec. Co. v. Imperial Irrigation Dist., 85 F.2d 886, 902 (9th Cir. 1936); Home Builders Ass'n of Central Ariz., Inc. v. Riddell, 109 Ariz. 404, 407, 510 P.2d 376, 379 (1973); City of Buena Park v. Boyar, 186 Cal. App. 2d 61, 66, 8 Cal. Rptr. 674, 679 (1960); Town of Fort Lupton v. Union Pac. R.R., 156 Colo. 352, 354, 399 P.2d 248, 249 (1965); City of Treasure Island v. Strong, 215 So. 2d 473, 474-75 (Fla. 1968); Oliver T. Beauchamp, Jr., Post No. 94 v. Somerset County Sanitary Comm'n, 243 Md. 98, 102, 220 A.2d 135, 137 (1966); Andrews v. County of Jackson, 43 Mich. App. 160, 163, 203 N.W.2d 925, 927 (1972); Soncoff v. City of Inkster, 22 Mich. App. 358, 361, 177 N.W.2d 243, 245 (1970); Independent School Dist. No. 709 v. City of Duluth, 287 Minn. 200, 20304, 177 N.W.2d 812, 815 (1970); Jardine v. Borough of Rumson, 30 N.J. Super. 509, 515, 105 A.2d 420, 423 (1954); Sisters of St. Mary, Inc. v. City of Beaverton, 4 Ore. App. 297, 299, 478 P.2d 412, 413 (1970); State v. City of Normandy Park, 64 Wash. 2d 411, 423, 392 P.2d 207, 215 (1964); E. MCQuillin, MunicipsL Corporations $\$ 38.32$ (1970); Johnston, supra note 60, at 875-76. In Associated Home Builders v. City of Walnut Creck, 4 Cal. $3 d 633,484$ P.2d 606 (1971), the court upheld a fee in lieu of dedication on the ground that a special benefit would accrue to the subdivisions assessed. See note 72 supra. The Court noted, for example,- that the relevant statute required that the particular subdivision benefit from the dedication or expenditure, and that this be ensured by the location of the park. Id. at $637,640,484 \mathrm{P} .2 \mathrm{~d}$ at $609,612,94$ Cal. Rptr. at 633, 635-36. Although the court's holding seems correct under the special assessment theory, its dictum 
benefit does not refer to benefits arising from the right to subdivide, but rather to benefits arising out of the improvement which was financed by the exaction. By analogy, in the context of TDR the benefit ensues from the preservation of a landmark, rather than from the right to increase the floor area of the building. The benefit is generally measured in terms of the increment in the value of the land which results from the improvement; ${ }^{80}$ however, the benefit need not be reflected in any present increment in property value, and any advantage which may accrue to the property in the future, contingent upon a change in use which can reasonably be anticipated, may be considered. ${ }^{81}$

Under the special assessment theory there is a presumption in favor of the legislative determination that a special benefit has accrued to the lands assessed. ${ }^{82}$ In earlier cases the legislative presumption appears to have been given great force, requiring flagrant abuse or arbitrariness to be demonstrated. ${ }^{83}$ However, more recent cases suggest that the presumption merely shifts the burden of proof to the party challenging the assessment to show that no benefits could reasonably be expected to accrue from the improvement. ${ }^{84}$

is more questionable. The court suggests that it might be willing, if faced with a case raising the issue, to uphold a fee in lieu of dedication even though the benefit may not enure to the particular subdivision assessed, i.e., to purchase land "some distance from the subdivision but which would also be available to the subdivision residents." Id. at 640 n.6, 484 P.2d 612 n.6, 94 Cal. Rptr. at 636 n.6. The rationale would be that the subdivision diminishes the supply of open land and adds residents who require park space within the city as a whole. Id. Such statements similarly suggest that the court might be willing to uphold a fee charged to developers for development rights on the theory that the development process creates pressure on landmarks, notwithstanding that a causal link could not be identified between particular developments and pressure on particular landmarks. Such a holding, however, would be a significant departure from existing case law. The possibility that a court might reach such a result in the future does not eliminate the substantial risks that the special assessment theory poses for the use of TDR.

80. Heavens v. King County Rural Library Dist., 66 Wash. 2d 558, 563-66, 404 P.2d 453, 456 (1956); $c f$. Soncoff v. City of Inkster, 22 Mich. App. 358, 361, 177 N.W.2d 243, 245 (1970) (benefit generally defined in terms of increment in land value, but may also be relief from a burden or production of a special adaptability in the land).

81. City of Owatonna v. Chicago, R.I. \& Pac. R.R., 450 F.2d 87, 89 (8th Cir. 1971); City of Hallandale v. Meekins, 237 So. 2d 318, 321-22 (Dist. Ct. App. Fla. 1970); Wharton v. City of Oskalooska, 158 N.W.2d 834, 835 (Iowa 1968); State v. City of Topeka, 201 Kan. $729,735,443$ P.2d 240, 246 (1970); Ridgewood Country Club v. Borough of Paramus, 55 N.J. $62,68.69,259$ A.2d 218,222 (1970).

82. Milheim v. Moffat Tunnel Improvement Dist., 262 U.S. 710, 721 (1923); Nev-Cal Elec. Sec. Co. v. Imperial Irrigation Dist., 85 F.2d 886, 901-02 (9th Cir. 1936); City of Owatonna v. Chicago, R.I. \& Pac. R.R., 450 F.2d 87, 92 (8th Cir. 1971); City of Hallandale v. Meckins, 237 So.2d 318, 321 (Dist. Ct. App. Fla. 1970); Andrews v. County of Jackson, 43 Mich. App. 160, 163, 203 N.W.2d 925, 927 (1972); In re Village of New Brighton Resolution 862, 293 Minn. 356, 359, 199 N.W.2d 435, 437 (1972); Heyman \& Gilhool, supra note 68 , at 1148 .

83. See, e.g., Milheim v. Moffat Improvement Tunnel Dist., 262 U.S. 710, 721 (1923).

84. See, e.g., City of Plymouth v. Superior Court, 8 Cal. App.3d 454, 463, 86 Cal. Rptr. 535, 541 (1970); Andrews v. County of Jackson, 43 Mich. App. 160, 163, 203 N.W.2d 925, 927 (1972); In re Village of Brighton Resolution 862, 293 Minn. 356, 359, 199 N.W.2d 435, 439 (1972). 
A second requirement under the special assessment theory is that of proportionality. ${ }^{85}$ No subdivision may be assessed for more than its proportionate share ${ }^{86}$ of the cost of the improvement. ${ }^{87}$ The presumption in favor of legislative validity does not appear to have been extended generally to the requirement of proportionality. ${ }^{88}$

In applying the special assessment theory to TDR, it first must be determined whether those specially assessed receive some benefit from the preservation of the landmark which is distinct from any benefit enjoyed by the general public. The parcels subject to the assessment are those in the transfer district. If the transfer district is restricted to the parcels adjacent to the landmark (including across the street), a special benefit may accrue to these parcels. This special benefit may be defined in terms of traditional land use theory: an adjacent lot benefits from the low landmark in terms of light and air. ${ }^{80} \mathrm{~A}$ transfer district consisting solely of immediately adjacent parcels, however, is

85. In considering fees in lieu of dedication of land for recreational purposes, the courts appear to have emphasized the requirement of proportionality at the expense of the special benefit requirement. Frequently such fees fail to meet the special benefit requirement because expenditures from the fund may be made for the purchase of park land in any part of the municipality. If the park lands dedicated are within the subdivision assessed, the requirement of a special benefit is met. A problem arises, however, where individual subdivisions are too small and too scattered to contribute any land useful for park purposes. If additional recreational facilities are not provided, the occupants of subdivisions which did not dedicate land will receive the benefits of park lands but without contributing their share of the payment. In order to establish proportionality by distributing the burden of providing recreational facilities among all subdividers, a fec in lieu of dedication may be appropriate in the situation of small and scattered subdivisions. This is the limited ground upon which courts have upheld the validity of such fees. See Associated Home Builders of the Greater East Bay, Inc. v. City of Walnut Creek, 4 Cal. 3d 633, 637, 484 P.2d 606, 609, 94 Cal. Rptr. 630, 633 (1971); Jenad, Inc. v. Village of Scarsdale, 18 N.Y.2d 78, 84, 218 N.E.2d 673, 676, 271 N.Y.S.2d 955, 958 (1966). But see Home Builders Ass'n of Central Ariz., Inc. v. Riddell, 109 Ariz. 404, 407, 510 P.2d 376, 379 (1973) (the court strictly applied the special benefit requirement and invalidated a provision for fees in lieu of dedication).

86. Proportionality will exist if the assessment is equal to the mathematical product of the ratio between the benefit to the developer's land and the benefit to all of the land, multiplied by the total cost of the improvement or preservation. Wexler, Betterment Recovery: A Financial Proposal For Sounder Land Use Planning, 3 Yale Rev. OF L. \& Soc. Acrion 192, 196 (1973).

87. City of Owatonna v. Chicago, R.I. \& Pac. R.R., 450 F.2d 87, 92 (8th Cir. 1971); Home Builders Ass'n of Central Ariz., Inc. v. Riddell, 109 Ariz. 404, 407, 510 P.2d 376, 379 (1973); Oliver T. Beauchamp, Jr., Post 94 v. Somerset County Sanitation Comm'n, 243 Md. 98, 102, 220 A.2d 135, 138 (1966); Stybel Plumbing, Inc. v. City of Oak Park, 40 Mich. App. 108, 114, 198 N.W.2d 782, 784 (1972); In re Village of New Brighton Resolution 862, 293 Minn. 356, 360-61, 199 N.W.2d 435, 438 (1972); Gulest Associates, Inc. v. Town of Newburgh, 25 Misc. 2d 1004, 1007, 209 N.Y.S.2d 729, 732 (Sup. Ct. 1960), aff'd, 15 App. Div. 2d 815, 225 N.Y.S.2d 538 (1962); overruled on other grounds sub nom. Jenad, Inc. v. Village of Scarsdale, 18 N.Y.2d 78, 218 N.E.2d 673, 271 N.Y.S.2d 955 (1966).

88. See, e.g., Home Builders Ass'n of Central Ariz., Inc. v. Riddell, 109 Ariz. 404, 407, 510 P.2d 376,379 (1973) (although ordinance stated that the taxes would bear a direct relationship to the persons affected by the tax, it would not be presumed that special benefits actually existed in proportion to the taxes imposed); Gulest Associates, Inc. v. Town of Newburgh, 25 Misc. 2d 1004, 1007, 209 N.Y.S.2d 729, 732 (Sup. Ct. 1960), aff'd, 15 App. Div. 2d 815, 225 N.Y.S.2d 538 (1962), overruled on olher grounds sub nom. Jenad, Inc. v. Village of Scarsdale, 18 N.Y.2d 78, 218 N.E.2d 673,271 N.Y.S.2d 955 (1966).

89. Elliott \& Marcts, supra note 1 , at 74 . 
unlikely. ${ }^{00}$ Generally, land adjacent to the preservation parcel would have to be developed at an extremely low density (or be undeveloped) for it to be profitable to purchase development rights, raze the existing structure and replace it with a new one utilizing the available surplus floor area. If adjacent buildings (which have not received landmark designation) are being maintained at low densities, it is probably because there is no market pressure to devote the parcels to more intensive use. However, under these circumstances, it is likely that there would also be no pressure on the landmark site. Therefore, it probably would not have been necessary in such a situation for the city to act to preserve the landmark.

Even assuming that a transfer district can exist which satisfies the special benefit requirement, it is unlikely that.TDR would ordinarily meet both the special benefit and the proportionality requirements. In identifying a transfer district, all lands specially benefited must be included, and only lands specially benefited may be included. ${ }^{01}$ Proportionality thus cannot exist unless each parcel in the transfer district purchases its respective share of the development rights for sale, and it seems unlikely that this requirement would ever be satisfied in practice. 92 Moreover, the purpose of most preservation efforts is not to benefit adjacent parcels, or even parcels in an extended transfer district. Rather, the purpose of landmark preservation is to benefit the entire community. Accordingly, at least part of the value of the development rights of a landmark must be allocated to the community at large under the proportionality requirement of the special assessment theory.

\section{Conclusion}

TDR is likely to be challenged by landmark owners unless the market for development rights accurately reflects the value of their condemned development potential. A constitutional attack on TDR

90. Cf. J. Costonis, supra note 1 , at 55,60 .

91. Jeffrey v. City of Salinas, 232 CaI. App. 2d 29, 38, 42 Cal. Rptr. 486, 493 (1965); Village of South Jacksonville v. Emberton, 52 Ill. App. 2d 90, 95, 201 N.E.2d 545, 547 (1964); Stybel Plumbing, Inc. v. City of Oak Park, 40 Mich. App. 108, 114, 198 N.W.2d 782, 784 (1972); Quality Homes, Inc. v. Village of New Brighton, 289 Minn. 274, 281, 183 N.W.2d 555, 559.60 (1971).

92. Furthermore, the cost of preservation (i.e., the amount paid to the landmark owner) may bear little relationship to the price at which the development rights are sold. Depending on market conditions, the total purchase price of the development rights may exceed or fall short of the payment made to the landmark owner. Therefore, the assessment paid by a developer may differ greatly from the amount calculated under the proportionality formula, since the sale price of the development rights may not accurately reflect the cost of preservation. 
will probably succeed. Courts have thus far viewed preservation measures based on TDR as a taking for which just compensation is required, and have found transferable development rights inadequate as compensation. The only methods available to a municipality to salvage its TDR system will shift the cost of preservation to developers in the transfer district. Developers may find convenient precedents in subdivision exaction case law for an attack on TDR. Application of either the police power or the special assessment theory to the sale of development rights leads to the conclusion that TDR systems are, in almost all situations, unconstitutional. Because these systems are likely to be challenged and invalidated, many great landmarks may be lost if municipalities continue to rely upon TDR as a means of landmark preservation. Municipalities would be well advised, therefore, to abandon TDR in favor of landmark preservation methods that are less vulnerable to constitutional attack. 